\title{
Behaviour Modification as An Effective Technique in Classroom Teaching
}

\author{
Obibuba, Ijeoma Martha \\ Department Of Primary Education School Of Early Childhood Care And Primary Education. Nwafor Orizu \\ College Of Education Nsugbe, Anambra State
}

\begin{abstract}
This study investigated of teachers' perception of the use of behaviour modification techniques in reducing truancy among primary school pupils in the Onitsha Education zone, Anambra State, Nigeria. Secondly, the study also examined the effectiveness of the various behaviour modification strategies employed by teachers in checking truancy in Onitsha Education Zone. The study used qualitative research methodology such as focus group discussion, key informant interview and questionnaire to elicit information from the respondents. The study population of the study was primary school teachers in the zone. A sample size of 250 respondents was selected. The teachers were randomly selected from 10 public primary schools. In each of the ten selected schools, (15 female and 10 male respondents were selected as samples making it 100 . The stratified random sampling technique was used to select the respondents from different strata. The study used descriptive statistics for hypotheses testing. The results from our findings reveal that there is no significant difference in mean score of male and female teachers' perception in use of behaviour modification techniques in the classroom. This connotes that the respondents have positive reactions to behaviour modification techniques in the study area. In addition, empirical analysis from our findings reveals further that commending a truant who starts attending lessons will make him/her to improve, promising a truant a pen any day he comes to school will encourage him/her to come often. That is, by implication, the study found significant negative relationship between material and non-material motivations and behaviour modification among primary school pupils in the study area. This indicates the effectiveness of the behaviour modification techniques in the study areas. Based on the results of our findings, this study recommends that the government through the ministry of education both at the federal, state and local levels should liaise with school authorities, Non-governmental organizations and relevant stakeholders to organize seminars and workshops to educate teachers on the appropriate use of behaviour modification techniques in order to revamp the system and structure of education in Nigeria.
\end{abstract}

Keywords: Behaviour modification techniques, truancy, material and non-material motivations, perception, effectiveness.

DOI: $10.7176 /$ RHSS/10-12-04

Publication date:June 30th 2020

\section{INTRODUCTION}

Behaviour became an important construct in early $20^{\text {th }}$ century psychology with the advent of the paradigm known subsequently as "behaviourism". Behaviourism was a reaction against faculty psychology which was purported to see into or understand the mind without the benefit of scientific testing.

Behaviour is an activity of an individual due to his/her interaction with the environment. It is the function of hereditary and environment. It is also the way an individual reacts or responds to a situation within his or her environment. These activities of an organism regarded as behaviour can be overt or covert. Overt behavior, are those behavior one can observe as one records the frequency of its occurrence. For instance noise making, sleeping, talking, jumping, etc. while covert behaviours are the internal activity of an organism that is not open to public perception. It is not readily available for objective measurement by a second person. However, it can be measured by self- observation or self reporting. Such behaviours are feelings like smoking, drinking, suicidal tendency, anger, etc.

Egbule (2009) defined behaviour as a unique set of complex activities performed by an individual which its origin from the biological and environmental factors surrounding the environment. According to Sharma et al (2018) opined that behaviour is the mirror in which everyone shows their image. That behaviour of a human being is determined by four primary factors namely, biological factors that are age and sex; biological factors which means how people interact with each other, cultural factors as regards the culture they belong to, and the situational factors are the environmental challenges they face. They also agreed that behaviours are strongly influenced by the interpersonal relationships. Human behaviour can be common, unusual, acceptable and unacceptable. Human beings evaluate the acceptability of behaviour using social norm and regulate behavior by means of social control. According to moral values, human behaviour may also depend on the common, usual, acceptable or unacceptable behaviour to others. Some of the behavior or reaction of pupils towards certain conditions or situations sometimes hinder their learning and that of other students and even prevent the teacher from achieving his or her set goal.

Moreover, modification literally means a process of improving upon the quality or performance of anything. 
The Advanced Oxford Dictionary $8^{\text {th }}$ edition defined modification as the act or process of changing something in order to improve it or make it more acceptable. Based on the above definition, a teachers use different traditional methods which include flogging, jumping like a frog, picking of pin, sitting on the air and even verbal abuse used by teachers have no relationship with the undesirable behaviour exhibited by students which the teachers want to modify.

Hence, these methods have no positive effect on modifying or changing the behaviour of students. Therefore, to modify students' behaviour, a systematic scientific way of changing the desirable behaviour should be applied (Mmaduakolam, 2008). Behavior modification is more effective in handling truant students than traditional methods or corporal punishments. This is because behaviour modification induces approachable behaviour or responses from the organism which traditional methods on the other hand may or may not have positive effect on the behaviour.

Historically, the origin of truancy can be traced to the Massachusetts Compulsory Education Act of 1647 and its subsequent School Attendance Act of 1852, which forced parents to send their children for at least 12 weeks in a term (Michael, 2005).

Therefore, truancy can be defined as intentionally absenting of oneself from school without permission, leaving without authorization and dodging of specific lesson periods. Nwana (2004) defines truancy among students as the act of absenting oneself from school without a legitimate reason and without permission.

Hukamdam (2011) described the clinical picture of truancy as that of staying off school as only one of the several kinds of anti-social behaviour such as stealing, lying, destructiveness and excessive fighting. Some truant students may come to school but avoid participating in school activities such as lessons, assemblies and other cocurricular activities. At such times, the students may be found hiding away in another part of the school either idling or engaging in some illegitimate activities.

Psychologists believe that behaviours can be learned and unlearned. Behaviour modification is attained through learning and other psychological principles. There are several behaviour modification techniques primary school teachers can employ to reduce truancy among the students. Such techniques may include proximity central, token economy, assertiveness, reinforcement punishment, timeout, pre-mark principle, contingency contracting, life modeling, role playing, self-management, etc. All these techniques are derived from various learning theories used in counseling relationships.

For order in the classroom, school, families and societies, students behaviour is expected to be acceptable by the teacher and general class. Application of the fundamental principles of behaviour modification inside and outside of the school by the teacher may foster better or acceptable behaviour in learners.

For instance, the realization that most maladaptive behaviour are products of negative background could be utilized by a teacher in the learning process to change or construct a meaningful and deeper learning in contrast to the knowledge in the existing scheme.

Anna Sutherland (2014) discovered that parental conflict and parental aggressiveness predicted involvement in property crime and truancy. Another study conducted by Asalu (2012) that children are more likely to resort to violence if there is violence within the relationships that they share with the family.

Finally, this research is to be carried out within some selected primary schools in Anambra State. The study is to find out the teachers' perception of the use of behaviour modification techniques in reducing truancy among primary school students in Anambra State.

According to Ezejiekwu (2009) perception can be seen as the process of knowing things, objects or events through the senses. It can also be seen as an awareness of the organic process. He goes further to say that it is a process that organizes meaning to sensation. Therefore, perception is the relay interception we give to sensation.

Behaviour modification techniques are the traditional terms for the use of empirically demonstrated behavior, such as altering an individual's behaviour and reactions to stimuli through his extension, punishment and or therapy.

The fundamental of behaviour modification techniques can be used to increase desired behaviour in any individual regardless of functional level. Behaviour modification techniques have been applied successfully in a wide variety of settings and with many types of behaviour and population (Sarafino; 1996). They have been used to correct children's problem behaviour, enhance instructional methods in schools, improve conduct in classroom, train developmentally disabled children in self-help skills, reduce substance abuse, reduce depression and anxiety, promote people's health and prevent illness and improve work productivity and safety.

According to Egbule (2009) the techniques used in modifying behaviour are quite varied. Operant techniques include some that deal with the consequences that strengthen the target behaviour. Positive reinforcement involves introducing a pleasant event after target behaviour and negative reinforcement involves removing and or reducing an aversive circumstance if target behaviour occurs.

Truancy is any international unauthorized or illegal absence from compulsory education. It is absence caused by pupils of their own free will and usually does not refer to legitimately "excused"' absence such as ones related to medical condition.

Truancy can be defined as absence that has not been authorized by the school and where leave has not been 
given or approved. It can be seen as pupils who have been registered with a school but identified as not attending school when the law says they should.

The development of behaviour modification among pupils shares much in common with other areas of behaviour modification in the field of mental health. Many early classroom studies were directed towards the reduction of "noxious" behaviours. The elimination of truancy, disruptive, out-of-seat and other behaviour that interfered with engaging school routines were frequently targeted for change. It appears that educators eagerly embrace procedures that would ease their difficulties in managing pupils who interfer with learning.

In the early $80 \mathrm{~s}$, a survey of recent and current application of behaviour modification in education suggested that studies of controlling properties of behaviour consequences had been very heavily emphasized. In many of the early studies in the field, the management of consequences accomplished little, although, many other researchers showed that the management of reinforcing and aversive consequences alone could accomplish a great deal. The principle of positive reinforcement holds that a positive reinforcement will increase the frequency of any behaviour it follows. This principle has been widely used in controlling truant behaviour amongst primary school pupils. This includes:

- Behaviour contract: In behaviour modification, behaviour contract is also called contingency management in a token economy. It is a written agreement between a teacher and a student. This agreement specifies the privileges a teacher will provide if a student behaves in a certain desirable way. Also, clearly specified in the contract, are bonuses for outstanding performance, penalties the student or teacher must pay for failing to meet the terms of the contract, the conditions under which the contract may be negotiated as well as expiration date (Okoli, 2002).

- Ear Shooting: This is a behaviour modification technique used in increasing and maintaining a desirable behaviour of a student. It entails eulogizing the good attitude or behaviour of a student in the presence of another person significant to the student in question to the hearing of the student. For example, a teacher could promote a student with truant behaviour by talking about his recent frequency in school with the parents in the presence of the student. The teacher talks about that attitude with the parents of the pupils in the presence so that the pupils will not only be happy but will continue in that behaviour. This technique strengthens and increases the frequent of coming to school of a truant student.

- Token Economy: Token economy represents a system in which expected behaviour is reinforced with tokens (primary reinforcers) and later exchanged for rewards (primary reinforcers). Token can be in the form of fake money, (dormy), stickers, symbols, etc. while rewards can be snacks, privilege and activities and so on: Nwankwo (2007) defines token economy as the technique which allows therapists to give conditioned reinforcers to individuals for behaving as targeted (in a desired manner). Here, conditioned reinforcers may include giving points, use of metals, card/tickets, symbols. These are later exchanged for books, pencils, erasers, buckets, privileges and so on as may have been agreed on by the therapist and the client. Token economy "can be effective if the teacher rewards a truant pupil for being present for a whole week and promise that more rewards await him if he will be frequent at school.

- Shaping: Shaping as the name suggests is a behaviour modification technique used to teach a new behaviour. The modifier or therapist does not wait until the client achieves the targeted desired behaviour before he/she is reinforced. But rather successive steps towards learning the desired behaviour are reinforced according to an increasingly rigorous criterion (Okoli, 2002). What the teacher does first is to give a clear description of what the child has to learn to do and then start by reinforcing something the child does that somehow resembles it. Progressively thereafter, behaviours, that increasingly approximate the desired behaviour, are reinforced until the child, consistently elicits the target behavior.

Shaping involves breaking down tasks into small steps, a chaining process, and then reinforcing the client as he accomplishes each step.

Arinze and Ojoru (2009) carried out an investigation on the topic the impact of cognitive behaviour modification strategy (CMBS) on youth readiness aptitude to cub aggression in the universities. The population of the study includes all youths in Nigerian schools. Purposive sampling techniques were employed to select University of Jos from which samples of 80 youths were randomly drawn. The instrument used at the pre-test and post test stages was the researcher's designed questionnaire.

One research question and hypothesis were posed and postulated respectively for the study. The data generated were analyzed using percentages and t-test statistics for related samples. The findings of the study showed that cognitive behaviour modification strategy had a positive and significant effect on youth readiness aptitude to curb aggressiveness.

It was also discovered that there was a significant difference in the mean achievement score of the youths at the pre and post test stages. The study will help both the teachers and pupils. To the pupils it would enable them to know that achievement in school is correlated to behaviour modification while to the teachers, it will enable them adopt appropriate strategies towards enhancing students' behaviour.

Sharma et al (2015) carried out a research on the five most common behaviours seen in the classroom using 
the following behavioural modification strategies. It was an experimental pre-post study design. Participants and school authority were briefed about the nature of the study, the duration of intervention of the study, and intervention and its benefits in the language best understood by them. They were encouraged to clarify queries regarding the study. A total of 140 participants were taken from the school, out of which 85 participants were randomly selected based on the inclusion and exclusion criteria, and through behaviour analysis sheet. About 7 participants were dumped out of the experiment for personal reasons. In sum, 78 participants were examined for the study. Their particular problematic behaviours were selected and the intervention for them were set. Interventions were given for a period of 8 weeks, twice per week and the lesson lasted for a period of 40-45 minutes. Daily assessment was taken on time sampling and frequency recording forms. Behaviour modification was applied.

It was discovered that baseline data of time sampling and frequency recording were collected and recorded on the first day before starting the intervention then at fourth week and then at the eight week. The results were analyzed through comparison of the result baseline. (Fourth week and eight week readings). The percentage increase or decrease in the behaviours was recorded according to the time sampling and frequency recording. This outcome shows that behaviour modification strategies are an effective technique to reduce problem behaviours shown by pupils in the classroom.

Okorie (2005) also conducted a research on cognitive behaviour therapy in improving the post primary school teachers in schools. This study investigated the differences in cognitive behaviour therapy (CBT) in achieving the cognitive behaviour of teachers in primary schools in Anambra state. Three research questions and three hypotheses tested at 0.05 level of significance guided the study. The sample of the study was 575 (283 males and 292 females) teachers that were from Njikoka (234) and Anambra were selected, through the stratified random sampling technique. 32 item was done with data collected, a self-made questionnaire on teachers cognitive behaviour therapy (TCBT) which was validated by experts. Mean and t-test analyses results no significant differences between teachers from other states. The finding showed that teachers' cognitive therapy (CBT) had a positive impact on teachers to improve on their education. It was also find out that teachers in urban areas go to school more than teachers in rural areas.

The present study emphasizes teachers' perception of the use of behaviour modification techniques in reducing truancy among primary school pupils.

This is important for the present study since peer mediation has proved effective; it has to be applied as a new strategy in behaviour modification.

A case study that was conducted in a public school on John, a twelve year old boy who often absented himself from school without permission from the school authority, Mrs. Nwaosu being his social studies teacher observed his truant behaviour and decided to draw him close to herself when he appears in school. First she promised to give him a story book if he completed the remaining four school days of that week since it was on a Monday. Since the little boy was not used to coming to school, he could not make it till Thursday. But instead of nothing, the teacher gave him a pen to write with and promised to do more if he could complete a five-school day. John made the first week and was reinforced by Mrs. Nwaosu. Next, she reinforced his frequency in school. After about three weeks of such shaping, John exhibited a normal frequency to school and on time too.

- Time out: This is a procedure that decreases the frequency of or eliminates an undesirable behaviour. Time out temporarily removes the opportunity to receive positive reinforcement. It is sometimes called removal punishment (Snowman and Biehler, 2003). Time out is adopted especially when a teacher believes that the attention of other students is a motivating tool to reinforce misbehaviour so that the student is denied of this reinforcement.

A case of a girl who leaves her home with school uniform every Friday only to hide at the back corner of the school until story telling period, simply because she hated mathematics. She walked into the class during story telling session and was assigned to time out as a consequence of her truant behaviour. Time out among others has generally been found to reduce truancy among primary school pupils.

In summary, behaviour modification is a procedure used psychologically to control, prevent or cure problems of human behaviour. Behaviour modification techniques have been applied successfully in a wide variety of settings and with many types of behaviours and populations. They have been used to reduce truancy among students, improve classroom conduct, train developmentally disabled children in self-help skills reduce substance abuse, improve work productivity and safety.

Behaviour modification has been used by many authorities in modifying undesirable behaviours and was found successful and effective. Teachers' perception on the use of behaviour modification techniques in reducing truancy was also found to be positive.

\section{Statement of the Research Problem}

Truancy has been identified as a major challenge among primary school pupils in schools globally and in Nigeria in particular most especially in Onitsha Education zone. (Animashaun, 2002).

Policymakers and educational practitioners have put some behaviour modification techniques in place to be 
employed by teachers in checking truancy among primary school pupils in Nigeria and Onitsha Education Zone in particular.

However, the behaviour of primary school pupils has been a major concern to educational psychologists and counselors' across the country over time. For instance, according to reports from the World Bank Development Indicators (2018), Onitsha Education zone contributes about $9 \%$ to the statistics of out-of-school children in Nigeria. Deviant behaviours have been noticed among primary school pupils. This may have negative effects on pupils' learning behaviour resulting in poor academic performance. Therefore, it is against this backdrop that this study intends to answer the following research questions:

I. What are teachers' perceptions on the use of behaviour modification techniques in reducing truancy among primary school pupils in Onitsha Education zone?

II. What is the degree of effectiveness of the various behaviour modification techniques employed by teachers in checking truancy in Primary schools in Onitsha Education Zone?

\section{METHODOLOGY \\ RESEARCH DESIGN}

The approach that was adopted in the execution of this study is the qualitative survey design as used by Uwalem (2018) and Davanzo (2015). This study research design used the qualitative research method. This includes crosssectional micro primary data obtained through questionnaire, focus group discussion (FGD) and key-informant interview to elicit responses from the respondents in the study area.

\section{AREA OF THE STUDY}

The study was carried out in Anambra State using five selected primary schools from Onitsha Zone which is in the Urban and most developed area in that commercial city of which Onitsha zone has been ranked best in the state.

\section{POPULATION OF THE STUDY}

The population of the study consisted of primary school teachers selected randomly from the Onitsha educational zone. In addition, the population of this study was further divided into two groups, namely: Three girls secondary schools and two mixed secondary schools were selected from the study area.

Sample and Sampling technique

Following the studies of Oshinowo (2016), Daniel (2017) and Ezekweche (2018), the study selected a sample size of 250 teachers in five primary schools in the Zone. The teachers were randomly selected from the study area. In each of the five selected schools, 15 female and 10 male teachers were selected randomly. The stratified random sampling technique was used to select the respondents from different strata.

\section{INSTRUMENT OF DATA COLLECTION}

A self-structured questionnaire was used for the purpose of this study, Teachers' Perception of the Use of Behaviour Modification Techniques in Reducing Truancy (TPMMTRT). It was made up of two phases. Phase one contains sections A and B. Section A contained personal information about the responds and section B was made up of twenty items designed to find out the teachers' - perception of the use of behavior modification techniques in reducing truancy among secondary school students. All the items in section B were structured on a four rating scale of;

$\begin{array}{ll}\text { Strongly Agree } & (\mathrm{SA})=4 \\ \text { Agree } & (\mathrm{A})=3 \\ \text { Disagree } & (\mathrm{D})=2 \\ \text { Strongly Disagree } & (\mathrm{SD})=1\end{array}$

However, phase two of the questionnaire contained the evaluation of the various behavioural modification techniques employed by the respondents to curb truancy among the pupils. All the parts in this phase were structured into the following:

Very often

Often

$(\mathrm{VO})=4$

Occasionally

$(\mathrm{O})=3$

Never

$$
(\mathrm{OC})=2
$$

(N) $=1$

\section{VALIDITY OF THE INSTRUMENT USED}

The face validity of the instrument was determined by three experts in educational research for vetting. Corrections were made and approval was given; thereby, making the instrument valid. 


\section{RELIABILITY OF THE INSTRUMENT}

The reliability of the instrument was established through one week interval test re-test co-efficient of reliability with 7.6. The reliability co-efficient was considered high enough and suitable for use in the study.

\section{METHOD OF DATA COLLECTION}

The study used focus group discussion, key-informant interview and questionnaire to elicit information from the respondents.

\section{METHOD OF DATA ANALYSIS}

The study used descriptive statistics to address the research questions raised in this study across the entire zone. Based on the nature of the study, the mean score of 2.50 and above was accepted while a value below 2.50 was rejected. Standard deviation was used to answer research questions while independent t-test was used to test the hypotheses.

\section{PRESENTATION AND ANALYSIS OF DATA}

The result of data generated from this study were organized and presented in this chapter. The presentation was done according to each research question and hypothesis.

DATA PRESENTATION AND ANALYSIS OF RESULTS

What are teachers' perceptions on the use of behavior modification techniques in the classroom?

Table1: Analysis of the response from Teachers' perceptions on the use of behaviour modification techniques in the classroom.

\begin{tabular}{|c|c|c|c|c|c|c|c|c|c|}
\hline $\mathbf{S} / \mathbf{N}$ & Items & $\mathbf{S A}$ & $\mathbf{A}$ & D & SD & EX & $\bar{\chi}$ & SD & DEC \\
\hline 1 & $\begin{array}{l}\text { Commending a truant who starts attending lessons } \\
\text { will make him to improve }\end{array}$ & 35 & 42 & 15 & 8 & 304 & 3.04 & 1.2 & $\mathrm{ACC}$ \\
\hline 2 & $\begin{array}{l}\text { Promising a truant a pen any day he comes to school } \\
\text { will encourage him to come often }\end{array}$ & 37 & 36 & 26 & 1 & 271 & 2.71 & 0.4 & $\mathrm{ACC}$ \\
\hline 3 & $\begin{array}{l}\text { Promising a perpetual late comer a gift any day he } \\
\text { comes to school on time will help him change instead } \\
\text { of flogging him }\end{array}$ & 45 & 26 & 28 & 1 & 315 & 3.15 & 0.65 & $\mathrm{ACC}$ \\
\hline 4 & $\begin{array}{l}\text { Clapping for students who come to school regularly } \\
\text { to motivate others will help truant ones towards } \\
\text { coming to school regularly }\end{array}$ & 34 & 41 & 14 & 11 & 298 & 2.98 & 0.48 & $\mathrm{ACC}$ \\
\hline 5 & $\begin{array}{l}\text { Keeping a disruptive student in a mapped out corner } \\
\text { for some minutes when an interesting lesson is going } \\
\text { on will make the student change instead of kneeling } \\
\text { him down }\end{array}$ & 8 & 38 & 40 & 14 & 2.40 & 2.40 & 0.1 & Rej \\
\hline 6 & $\begin{array}{l}\text { Commending a late comer who walks into class to } \\
\text { greet good morning to the class members will make } \\
\text { the student to improve }\end{array}$ & 8 & 38 & 40 & 14 & 2.40 & 2.40 & & Rej \\
\hline 7 & $\begin{array}{l}\text { Taking attendance in the morning, after noon and } \\
\text { before closure will make a truant to be regular in } \\
\text { school }\end{array}$ & 52 & 32 & 11 & 5 & 331 & 3.31 & 0.81 & Acc \\
\hline 8 & $\begin{array}{l}\text { Giving awards to a truant will encourage him to start } \\
\text { coming to school }\end{array}$ & 33 & 37 & 18 & 12 & 2.91 & 2.91 & 0.41 & Acc \\
\hline 9 & $\begin{array}{l}\text { Showing a truant the film of the repercussion of } \\
\text { truancy will make him change and start coming to } \\
\text { school }\end{array}$ & 36 & 32 & 22 & 10 & 294 & 2.94 & 0.14 & Acc \\
\hline 10 & $\begin{array}{l}\text { Praising a truant each day he comes to school to his } \\
\text { hearing in the presence of his classmates will make } \\
\text { him put more effort. }\end{array}$ & 42 & 33 & 13 & 12 & 305 & 3.05 & 0.55 & Acc \\
\hline
\end{tabular}

The empirical statistical results obtained from Table 1 above show that 8 items out of ten items scored mean above 2.50indicating the teachers' perceptions on the use of behaviour modification techniques in the classroom is highly effective. Item (3) scored a mean 0f 3.15, item (4) scored 2.98, item (7) scored 3.31, item (8) scored 2.91, item (9) scored 2.94, and item (10) scored 3.05. On the other hand, the items with low means are indications of techniques not employed by teachers in order to modify truancy in the study area. These are items 5 and 6 with mean scores of 2.40 . 
However, the standard deviations of all the variables of interest whose mean scores fall within the acceptance region of the study apriori expectation were all accepted. By implication, this means that teachers' perceptions about the behaviour modification techniques in the classroom have achieved their desired results.From the empirical standpoint, the results of our findings in the analysis of table 1 above actually key into the findings of Oshinowo (2016), Daniel (2017) and Ezekweche (2018).

RESEARCH QUESTIONS 2

Is the Behaviour Modification technique employed by primary school teachers for Modifying Truancy among primary school pupils in Onitsha Education Zone effective?

Table 2: Analysis of Teachers response on the effectiveness of behavior modification technique in the classroom.

\begin{tabular}{|c|c|c|c|c|c|c|c|c|c|c|}
\hline Variables & $\begin{array}{l}\text { Very } \\
\text { often }\end{array}$ & often & Occasionally & Rarely & Never & $\mathbf{N}$ & $\Sigma X$ & $\overline{\mathbf{X}}$ & SD & DEC \\
\hline $\begin{array}{l}\text { Commending a truant } \\
\text { who starts attending } \\
\text { lessons will make him } \\
\text { to improve }\end{array}$ & 98 & 83 & 68 & 39 & 28 & 300 & 1192 & 3.68 & 1.3 & ACC \\
\hline $\begin{array}{l}\text { Promising a truant a } \\
\text { pen any day he comes } \\
\text { to school will } \\
\text { encourage him to } \\
\text { come often }\end{array}$ & 97 & 49 & 34 & 34 & 23 & 56 & 956 & 3.50 & 0.9 & ACC \\
\hline $\begin{array}{l}\text { Promising a perpetual } \\
\text { late comer a gif any } \\
\text { day he comes to } \\
\text { school on time will } \\
\text { help him change } \\
\text { instead of flogging } \\
\text { him }\end{array}$ & 89 & 67 & 23 & 41 & 23 & 15 & 1185 & 3.60 & 0.78 & ACC \\
\hline $\begin{array}{l}\text { Clapping for students } \\
\text { who come to school } \\
\text { regularly to motivate } \\
\text { others will help truant } \\
\text { towards coming to } \\
\text { school regularly }\end{array}$ & 98 & 79 & 45 & 39 & 28 & 15 & 1030 & 3.40 & 0.58 & ACC \\
\hline $\begin{array}{l}\text { Keeping a disruptive } \\
\text { student in a mapped } \\
\text { out corner for some } \\
\text { minutes when an } \\
\text { interesting lesson is } \\
\text { going on will make the } \\
\text { student change instead } \\
\text { of kneeling him down }\end{array}$ & 96 & 88 & 67 & 56 & 29 & 20 & 1028 & 3.11 & 0.7 & ACC \\
\hline $\begin{array}{l}\text { Commending a late } \\
\text { comer who walks into } \\
\text { class to greet good } \\
\text { morning to the class } \\
\text { members will make } \\
\text { the student to improve }\end{array}$ & 78 & 68 & 59 & 60 & 45 & 15 & 797 & 3.20 & & ACC \\
\hline $\begin{array}{l}\text { Taking attendance in } \\
\text { the morning, after } \\
\text { noon and before } \\
\text { closure will make a } \\
\text { truant to be regular in } \\
\text { school }\end{array}$ & 98 & 78 & 67 & 30 & 25 & 20 & 1160 & 3.12 & 0.91 & Acc \\
\hline
\end{tabular}




\begin{tabular}{|c|c|c|c|c|c|c|c|c|c|c|}
\hline Variables & $\begin{array}{l}\text { Very } \\
\text { often }\end{array}$ & often & Occasionally & Rarely & Never & $\mathbf{N}$ & $\Sigma X$ & $\overline{\mathbf{X}}$ & SD & DEC \\
\hline $\begin{array}{l}\text { Giving awards to a } \\
\text { truant will encourage } \\
\text { him to start coming to } \\
\text { school }\end{array}$ & 68 & 56 & 78 & 34 & 56 & 27 & 989 & 3.50 & 0.41 & Acc \\
\hline $\begin{array}{l}\text { Showing a truant the } \\
\text { film of the } \\
\text { repercussion of } \\
\text { truancy will make him } \\
\text { change and start } \\
\text { coming to school }\end{array}$ & 99 & 68 & 78 & 67 & 54 & 34 & 1191 & 2.15 & 0.19 & REJ \\
\hline $\begin{array}{l}\text { Praising a truant each } \\
\text { day he comes to } \\
\text { school to his hearing } \\
\text { in the presence of his } \\
\text { classmates will make } \\
\text { him put in more } \\
\text { efforts. }\end{array}$ & 98 & 78 & 56 & 46 & 48 & 24 & 1189 & 3.45 & 0.66 & Acc \\
\hline
\end{tabular}

TABLE 2: Teachers' Responses on the Effectiveness of Behaviour Modification techniques Employed by Primary School Teachers for Modifying Truancy as a Bad Behaviour in Onitsha Education Zone.

The results obtained from Table 2 above depict that 9 out of ten items scored a mean above 2.50 indicating the effectiveness of the techniques teachers employed to modify truancy among pupils. Item (1) scored a mean of 3.68, item (2) scored 3.50, item (3) scored 3.60, item (4) scored 3.40, item (5) scored 3.11, and item (6) scored 3.20 while item (7) scored a mean of 3.12, item (8) scored 3.50, and item (10) scored 3.45. The items with a low mean denotes that the technique employed by teachers in order to modify truancy among primary school pupils in the study area is not effective. This empirical result is in line with the studies of Safiyanu (2017), Ariwodola and Arowolo (2018).

\section{SUMMARY AND CONCLUSION}

This study is investigated teachers' perception on the use of behaviour modification techniques and effectiveness of the behaviour modification techniques in reducing truancy among primary school pupils in Anambra State. Therefore, based on the outcomes of our findings, it was discovered that primary school teachers have a positive perception on the use of behaviour modification techniques in the classroom.

Moreover, the study equally revealed that both male and female respondents adopted the behaviour modification techniques in the classroom. Majority of the respondents attested to the fact that behaviour modification techniques are an effective tool in curbing truancy among primary school pupils. This statement also corroborated the views of our Focus Group Discussion and key-informant interview participants.

However, two research questions were raised in the course of the analysis of the problems in this study. From the data analyzed, results from the first research question revealed that primary school teachers have a positive perception on the use of behaviour modification techniques on the classroom except item five (5) which states that keeping a disruptive student in a mapped corner for some minutes when an interesting lesson is going on will make the student change instead of kneeling him down. This is also referred to as time out in behaviour modification. It is argued that pupils on time out are happy when they are sent out from the class. They use the opportunity to interact with other stubborn pupils sent out from other classes.

In addition, the analysis of the results from table 1 further revealed that male and female teachers have a positive perception on the use of behaviour modification technique in the classroom. There is no significant difference in the mean scores of male and female teachers on the use of behaviour modification techniques in the classroom. The results from our analysis in table 1 above are in line with the findings of Oshinowo (2016), Daniel (2017) and Ezekweche (2018).

However, the empirical results from the second research question raised in this study which is depicted in table 2 also show that the use of behaviour modification techniques in the classroom is effective in curbing truancy among primary school pupils in the study area except item nine (9) which shows a somewhat ineffectiveness. In addition, the empirical findings from Safiyanu (2017), Ariwodola and Arowolo (2018) actually corroborated the results of our findings in table 2 which addresses the second research question.

\section{RECOMMENDATIONS:}

Based on our empirical findings, the following recommendations were made:

1. The government through the ministry of education in the state should liaise with school authorities, Non- 
Governmental Organizations and relevant stakeholders to organize seminars and workshops to educate teachers on the appropriate use of behaviour modification techniques.

2. School counselors should, from time to time organize teachers' forum to re-educate teachers on the relevance of using behaviour modification techniques in modifying pupils.

3. Teachers should endeavour to apply the techniques in every day teaching to bring about desirable change in the behaviour of the pupils.

4. School authorities should reinforce the use of behaviour modification as an alternative to punishment.

\section{REFERENCES}

Andrew, M.C. (2003). Dictionary of psychology ( $3^{\text {rd }}$ edition) Oxford University Press.

Arinze A.G \& Ojprou, P.E. (2009). Impact of cognitive behaviour strategy on youth aggression in Nigerian Universities: conference proceedings for $34^{\text {th }}$ Annual National Conference of the counseling Association of Nigeria, held at Abuja

Anna Sutherland (2014). How parental conflicts hurt kids.

Ariwodola, J.K. \& Arowolo, Y.U. (2018). Analysis of behavioural modification techniques in some selected primary schools in Ogun Western Education Zone. Journal of Educational Research, 7, (1), 23-45.

Bandura, A. (1977). Social learning theory. Eaglewood Cliffs, N.J: Prentice Hall.

Egbule, J.F. (2009). Principle and techniques of behavior modification ( $1^{\text {st }}$ edition). Benin City: Jeco press and publishers.

Ezekweche, C.U. (2018). Analysis of behavioural modification Techniques in some selected primary schools in Abia Western Education Zone. Journal of Educational Research, 4, (1), 10-30.

Daniel, F.O. (2017). Analysis of behavioural modification techniques in some selected primary schools in Jos Eastern Education Zone, Journal of Educational Research, 6, (1), 15-32.

Hukamdad, S.S. (2011). Comparison of teachers' and students' view on the use of behavior modification at the secondary school level. International Journal of academic research 3 (1) January

Kohler, W. (1925). The mentality of Apes. London: Routledge and Kegan Paul.

Michael, R.W. (2016). The importance of school attendance. Journal of crime

delinquency.

Mmaduakonam, A. (2005). Causes, forms and psycho sociology problems of bullying in secondary schools as perceived by adolescents in Anambra State Approaches International journal of development.

Nwankwo, C.A. (2007). Usability of behavior modification strategies in the Classroom. Journal of theoretical and empirical studies in education, 1 (1): 190-208.

Nwaria, (2004). Truancy among secondary school students in Ebonyi South.

Okoli, A. (2002). Education: A year of disaster at all levels. Vanguard publishers Lahore 12-13.

Okorie, C.K. (2005). The impact of moral instruction on student's behavior in secondary schools. Unpublished M.SD thesis of Ebonyi State University, Nigeria.

Oladele J.O. (2007). Guidance and counseling. A functional approach (4 ${ }^{\text {th }}$ edition) Lagos; Jolus Lad Publishers.

Onwusoanya, P.N. (2010). Behaviour modification strategies accessed from http;www.buzzle.com/article/behavoirmodificationstrategieson15/5/2010

Oshinowo, M.O. (2016). Analysis of behavioural modification techniques in some selected primary schools in Ilorin Western Education Zone. Journal of educational research, 1, (2), 56-95.

Safiyanu, A.B. (2017). Analysis of behavioural modification techniques in Some selected primary schools in Kaduna Northern Education Zone, Journal of Educational Research, 9, (7), 15-34.

Skinner, B.F. (1957). Science and human behaviour. Simon and Schuster.com

Snowman and Brehler (2006). Psychology applied to teaching (11 $1^{\text {th }}$ edition) place of publication: Wadsworth publishing.

Sharma et al (2018). Effectiveness of behaviour modification strategies in school going children for specific classroom behaviour.

Sharma A, Malawade M, Shrikhandes (2018) 